\title{
Poligami dan Perubahan Psikologi Tokoh Utama dalam Novel "Cinta di Tanah Haram" Karya Nucke Rahma
}

\author{
Henny Nopriani ${ }^{1 凶}$, Distiyana $^{2 \bowtie,}$ \\ STKIP Muhammadiyah Pagar Alam \\ nopriai_henny@yahoo.com, distiyana@gmail.com
}

\begin{abstract}
Literary work is one of the works in which imaginative story forms. However, have messages that you want to convey to the reader. For example the story of polygamy in the novel Cinta di Tanah Haram by Nucke Rahma, of course there are psychological changes experienced by the characters after polygamy. The purpose of this study is to describe polygamy and the changes experienced by the characters in the novel Cinta di Tanah Haram by Nucke Rahma. This research uses a descriptive method. The approach used in this research is the psychological literary approach. The data collection technique used in this research is literature study. The data source in this study is the novel Cinta in Tanah Haram by Nucke Rahma. The results of data analysis in the novel Cinta in Tanah Haram by Nucke Rahma is a form of attitude change due to polygamy. So the conclusions in this novel are the psychological changes that occur a lot in Nucke Rahma's Cinta di Tanah Haram novel. It is a change in Khumairah's character who was previously a person who fought for gender equality, but now Khumairah himself must feel how to surrender to injustice done Zidan to him.
\end{abstract}

Keywords: novel, polygamy, psychology

Abstrak : Karya sastra adalah salah satu karya yang bentuk ceritanya imajinatif. Namun, mempunyai pesan-pesan yang ingin disampaikan kepada pembaca. Misalnya cerita tentang poligami dalam novel Cinta di Tanah Haram karya Nucke Rahma,tentu terdapat perubahan-perubahan psikologis yang dialami tokoh setelah dipoligami. Tujuan penelitian ini untuk mendeskripsikan poligami dan perubahan yang dialami tokoh dalam novel Cinta di Tanah Haram karya Nucke Rahma. Penelitian ini menggunakan metode deskriptif. Pendekatan yang digunakan dalam penelitian ini adalah pendekatan psikologis sastra. Teknik pengumpulan data yang digunakan dalam penelitian ini adalah studi pustaka. Sumber data pada penelitian ini adalah novel Cinta di Tanah Haram karya Nucke Rahma. Hasil analisis data dalam novel Cinta di Tanah Haram karya Nucke Rahma merupakan bentuk perubahan sikap akibat adanya poligami. Hasil penelitian menunjukkan perubahan psikologi yang banyak terjadi dalam novel Cinta di Tanah Haram karya Nucke Rahma seperti perubahan pada tokoh Khumairah yang sebelumnya sebagai seorang yang memperjuangkan kesetaraan gender, namun kini Khumairah sendiri yang harus

Sitasi Jurnal:

Nopriani, H., \& Distiyana, D. (2020). Poligami dan Perubahan Psikologi Tokoh Utama dalam Novel "Cinta di Tanah Haram" Karya Nucke Rahma. Disastra: Jurnal Pendidikan Bahasa dan Sastra Indonesia, 2(1), 23-24. doi:http://dx.doi.org/10.29300/disastra.v2i1.2044 
merasakan bagaimana harus berpasrah diri menahan atas ketidakadilan yang dilakukan Zidan kepadanya

Kata Kunci : novel, poligami, psikologi

\section{Pendahuluan}

Karya sastra adalah sebuah karya tulis yang mengandung nilai seni sebagai hasil kreasi ekspresi dan keindahan bahasa di dalamnya serta pesan-pesan yang disampaikan kepada pembaca. Sebuah karya yang mempunyai nilai seni, sastra juga berisi ungkapan-ungkapan pribadi manusia yang berupa ide, pengalaman, perasaan, cita-cita, keyakinan dan semangat dalam bentuk gambaran konkret yang mampu membangkitkan pesona dengan menggunakan bahasa. Antara sastra dan bahasa mempunyai kolerasi yang positif, karena media yang digunakan dalam menciptakan karya sastra baik itu prosa, puisi, maupun drama dalam bahasa. Salah satu karya sastra yang membicarakan tentang masalah hidup dan kehidupan adalah novel.

Cerita dalam novel dapat berisi tentang sosial, agama, politik, budaya, dan poligami. Hal ini menunjukkan bahwa kehidupan manusia tidak terlepas dari adanya kejiwaan karena manusia senantiasa berpikir dan memperlihatkan perilaku yang beragam dalam kehidupan masyarakat. Salah satu novel yang menceritakan poligami adalah novel Cinta di Tanah Haram karya Nucke Rahman.

Poligami secara umum adalah suatu pernikahan yang banyak atau lebih dari seorang. Sistem perkawinan tersebut menunjukkan bahwa seorang laki-laki mempunyai istri lebih dari satu dalam waktu bersamaan. Hal ini terdapat dalam novel Cinta di Tanah Haram karya Nucke Rahman.

Berdasarkan latar belakang tersebut, peneliti tertarik untuk mengkaji judul
Analisis Poligami dan Perubahan Psikologi Tokoh Utama dalam Novel Cinta di tanah Haram Karya Nucke Rahma, karena hal-hal berikut. Novel Cinta di Tanah Haram merupakan salah satu novel yang menceritakan tentang poligami, novel Cinta di Tanah Haram karya Nucke Rahman merupakan novel yang Best Seller, novel Cinta di Tanah Haram berisi pesan yang inspiratif dan ilmu yang bermanfaat, serta memberikan nilai-nilai yang dapat dijadikan teladan untuk kehidupan seharihari.

Ahmad (2007) memaparkan bahwa poligami adalah sistem yang telah lahir sebelum Islam. Poligami menjadi sebuah sistem yang melekat di Arab yang dilaksanakan semata-mata untuk kebutuhan biologis oleh beberapa aspek masyarakat. Mulia (dikutip Ardian, 2015), mendefinisikan poligami merupakan bentuk pelecehan terhadap martabat perempuan, tindakan kekerasan, atau bahkan penindasan atas hak-hak wanita secara utuh. "Islam membolehkan poligami memberikan dua syarat, sanggup untuk memberikan dua syarat yaitu adil dan sanggup untuk memberikan nafkah. Adapun maksud dengan adil adalah adil dalam memberikan hak-hak istrinya, baik lahir maupun batin, dan merata dalam memberikan tempat, nafkah dan lainnya" (Ahmad, 2007). Sedangakan yang berhubungan dengan hati, maka dia tidak mungkin dapat melakukanya karena kasih sayingnya di antara istri-istrinya yang lain, kecantikan atau keistimewaan lainya. 


\section{Metode Penelitian}

Metode yang digunakan dalam penelitian ini adalah metode deskriptif. Metode deskriptif adalah penelitian yang dilakukan untuk mengetahui nilai masingmasing variabel atau lebih sifatnya independent tanpa membuat hubungan maupun perbandingan dengan variabel lain (Sujarweni, 2014). Sementara itu menurut Ratna (dikutip Tsaniyatsnaini, 2019) Metode deskriptif dilaksanakan dengan mendeskripsikan fakta-fakta yang ada kemudian disusun dengan analisis. Secara etimologis, deskripsi dan analisis memiliki pengertian menguraikan, memberikan pemahaman dan penjelasan secukupnya Penelitian ini dilakukan untuk menganalisis, poligami dan perubahan Psikologis tokoh utama dalam novel Cinta di Tanah Haram karya Nucke Rahma.

Pendekatan yang digunakan dalam penelitian ini adalah pendekatan psikologi sastra berdasarkan teori Kurt Lewin. Psikologi sastra adalah penelitian sastra yang membicarakan persoalan-persoalan manusia dari aspek kejiwaan baik pada teks yang terkait dengan perwatakan tokoh, proses kreatif, dan pembaca (Minderop, 2016). Psikologi sastra ini bertujuan memahami dan menganalisis aspek kejiwaan termasuk berkaitan dengan psikologi para tokoh dalam karya sastra.

Teknik pengumpulan data yang data yang digunakan dalam penelitian ini adalah teknik studi pustaka. Studi kepustakan adalah penyajian hasil dengan literature yang telah dilakukan oleh peneliti (Afrizal, 2015). Literature meliputi buku, artikel di jurnal dan makalah seminar. Bahan pustaka yang disajikan pada sumber data adalah "Analisis Poligami dan Perubahan Psikologis Tokoh Utama" dalam novel Cinta di Tanah Haram Karya Nucke Rahma.

Pengumpulan data dalam penelitian ini, dilakukan dengan riset kepustakaan, dengan cara sebagai berikut.

1. Membaca dengan cermat sertaberulangulang sehingga memahami makna secara utuh terhadap novel yang menjadi objek kajian penulis berdasarkan rumusan masalah dan tujuan dalam objek kajian.

2. Memberikan tanda pada kalimat atau teks yang termasuk dalam poligami dan perubahan psikologis tokoh utama.

3. Mengklasifikasikan data-data yang diperoleh dengan sumber data yang berkaitan dengan objek kajian, yaitu, analisis poligami dan perubahan psikologis tokoh utama.

4. Membuat sinopsis novel "Cinta di Tanah Haram" Karya Nucke Rahma.

Analisis dilakukan dengan pemamparan dalam bentuk deskriptif terhadap masingmasing data secara fungisonal dan relasional (Siswantoro, 2016). Teknik analisis data yang digunakan pada penelitian ini adalah teknik deskriptif. Teknik deskriptif adalah mendeskripsikan data-data sesuai dengan yang sebenarnya kemudian data-data tersebut disusun, diolah, dan dianalis. Peneliti menggunakan langkah kerja sebagai berikut.

1. Menganalisis poligami dan perubahan psikologi tokoh utama dalam novel Cinta di Tanah Haram.

2. Mengklasifikasikan hasil analisis poligami dan perubahan psikologis dalam novel Cinta di Tanah Haram.

3. Mendeskripsikan hasil analisis yang telah dikelompokkan tersebut dalam novel Cinta di Tanah Haram.

4. Menyimpulkan hasil novel Cinta di Tanah Haram. 
Data adalah sumber informasi yang akan diseleksi sebagai bahan analisis (Siswantoro, 2016). Oleh karena itu, kualitas dan ketepatan pengambilan data tergantung pada ketajaman menyeleksi yang dipandu oleh pengusaan konsep atau teori. Data dalam penelitian ini adalah kalimat yang berkaitan dengan poligami dan perubahan psikologis tokoh utama dalam novel Cinta di Tanah Haram karya Nucke Rahma.

Sumber data dalam penelitian ini adalah novel Cinta di Tanah Haram karya Nucke Rahma yang diterbitkan oleh Onbloss Creative 2016, cetakan pertama Januari 2015. Warna kulit coklat muda dan ungu, yang bergambar padang arafah serta bunga mawar merah dan putih, Tinggi buku kurang lebih $20 \mathrm{~cm}$ dan berjumlah 676 halaman.

\section{Hasil dan Pembahasan}

\section{Poligami yang Terdapat dalam Novel Cinta di Tanah Haram Karya Nucke Rahma}

Poligami adalah sebuah alternatif (solusi) yang boleh diberlakukan karena beberapa faktor atau keterpaksaan, dan keterpaksaan ini bersifat relatif. Islam membolehkan poligami, namun tidak menentukan persyaratan apapun secara tegas, jika seorang lak-laki melakukan kazaliman terhadap istri-istrinya. Analisis bentuk poligami dalam novel Cinta di Tanah Haram karya Nucke Rahma dalam dilihat pada kutipan berikut.

"Perempuan itukah yang telah
membuat Zidan kehilangan
gairahnya?pertanyaan itu membuat
Khumairah tersadar bahwa telah
banyak yang hilang dalam
pernikahanya. Ingin rasanya
Khumairah berlari sekencang
kejaran angin. Berhenti di hadapan

Zidan dan memuntahkan pertanyaan 'Mengapa, suamiku ?Mengapa kau tegamelakukan pengkhianatan itu? Apa yang salah dengan aku dan apa dosaku terhadap engkau, suamiku tercinta ?'Tapi Khumairah tidak mau berlari. Dia tetap berdiri tegak di balik pilar persembunyianya. Sepasang kakinya bagai dibelenggu oleh beban berat hingga tidak mampu melangkah mendekati Zidan. Dia memilih berlindung dalam ketakutanya menghadapi pengkhiantan yang dilkukan sang suami" (Rahma, 2015).

Pada kutipan di atas, digambarkan Khumairah yang memiliki sifat penyabar, iklas, dan salihah semua itu bisa terlihat kala datangnya ujian hidup yang menimpanya disaat mengetahui bahwa suaminya berpoligami. Disaat sedang mencari suaminya Khumairah mengalami shock berat. Setalah mengalami poligami yang terjadi pada Khumairah dan perubahan Khumairah, setelah mengetahui suaminya berkhianat, Khumairah lebih banyak diam, dan menutup diri tidak seperti yang biasa dia lakukan dengan Zidan. Khumairah lebih menjauhkan diri terhadap Zidan dan Khumairah berusaha menenangkan hatinya yang dijalari rasa tidak nyaman.Khumiarah lebih menyibukkan diri dengan aktivitas yang pernah Khumairah lakukan selama ini. Sosok Khumairah tidak pernah menyerah dan terus bersabar dalam menghadapi pengkhianatan yang dilakukan oleh suaminya yang berpoligami dengan seorang wanita yang bernama Viola.

"Kehidupan pernikahan adalah belantara hidup yang harus dijalani dengan sepenuh jiwa. Kesabaran dan saling pengertian adalah bahan bakar yang utama. Jika kedua sikap itu hanya 
dimiliki salah satu dari sepasang suami istri maka kehidupan berumah tangga akan timpang. Tujuan untuk menggapai bahagia akan sulit tergapai. Dalam pernikahan Khumairah dan Zidan, hanya Khumairah sendiri yang berjuang untuk menjaga kestabilan hubungan mereka, bahkan wanita yang seakan telah memiliki segalanya kecantikan dan kecerdasan itu rela menghamba demi silaturahmi cinta" (Rahma, 2015).

Pada kutipan di atas, digambarkan meski dengan perangai yang keras dan kerap menuntut banyak hal, pada mulanya pernikahan Zidan dan Khumairah berjalan harmonis. Namun, kekurangan yang ada pada Khumairah membuat Zidan berpaling pada wanita lain. Ironisnya perselingkuhan Zidan terkuak ketika Khumairah dan Zidan melakukan ibadah haji di Baitullah. Viola istri muda Zidan juga turut beribadah haji dan sering berada di lokasi yang sama. Namun, mengingat dirinya tengah melaksanakan ibadah Khumairah memilih untuk memenangkan haji mabrur, dibanding terpuruk oleh pengkhianatan Zidan. Bahkan Khumaira sempat menolong Viola yang tidak mengetahui bahwa dirinya adalah istri pertama lelaki yang Viola cintai.

"Ya, Allah. Dosa apa yang ia perbuat hingga Zidan tega mengkhianatinya? Padahal Zidanlah alasannya hidup dan mencinta. Mengapa cinta harus terbagi? Tak cukupkah pengabdiannya selama ini? Tak bisakah cinta setia hanya pada satu hati? Atau begitukah nasib seorang istri, tercampakkan ketika pesona mulai memudar? Alangkah kejamnya cinta. Ia menorehkan luka setelah memberikan kebahagiaan. Penyerahan dirinya atas cinta diganjar pengkhianatan dan dusta. Khumairah terluka, dia terpasung dalam dusta yang diciptakan suaminya." Khumairah merasa terguncang menyadari betapa baktinya sebagai makmum dalam pernikahannya dengan Zidan telah membalas air tuba". (Rahma, 2015).

Pada kutipan di atas digambarkan bagaimana Zidan dengan sengaja melukai perasaan Khumairah yang di dalam novel ini digambarkan sebagai makhluk yang lemah. Perempuan bukannya dilindungi, tetapi justru diperdayakan karena kelemahannya tersebut, baik oleh laki-laki di dalam rumah maupun oleh masyarakat di luar rumah.

"Ya, Allah. Dari mana datangnya
kepalsuan itu hingga suamiku merasa
wajar untuk berbohong? Atau jangan-
jangan Zidan terpaksa melakukan
dusta itu karena dia tidak berani
berterus terang tentang hubungan
gelapnya". (Rahma, 2015).

Pada kutipan di atas digambarkan bagaimana Khumairah harus menahan rasa sakit karena pengkhianatan yang dilakukan Zidan hingga membuat hatinya semakin terluka, Khumairah hanya terpaku dengan harga dirinya yang telah diinjak-injak oleh suami yang dianggapnya setia dengan melakukan perselingkuhan di muka umum.

"Ya Allah. Inikah maksud Zidan meminta aku bersumpah waktu itu? Ternyata dia telah berbuat khilaf dengan mengkhianati aku! Dan suamiku juga merasa, bahwa pengkhinatan itu adalah sebuah kesalahan yang sudah seharusnya aku maafkan? Adilkah semua ini, ya Allah?! Adilkah?!” (Rahma, 2015).

Kutipan dialog tersebut bagaimana kesabarannya pun mulai diuji, pengkhianatan 
itupun terjadi. Zidan lelaki yang dicintainya telah mengkhianati kesetiaan dan kesucian cinta Khumairah, Zidan yang telah menyembunyikan dustanya kepada Khumairah.

\section{Perubahan Psikologi Tokoh Utama dalam Novel Cinta di Tanah Haram Karya Nucke Rahma}

Psikologi kepribadian adalah psikologi yang mempelajari kepribadian manusia dengan objek penelitian faktorfaktor yang mempengaruhi tingkah laku manusia. Berikut beberapa perubahan psikologi tokoh dalam novel Cinta di Tanah Haram karya Nucke Rahma.

\section{Perubahan Psikologi Tokoh Khumairah}

Analisis bentuk perubahan psikologi tokoh Khumairah dalam novel Cinta di Tanah Haram karya Nucke Rahma dalam dilihat pada kutipan berikut.

"Beginikah rasanya takut kehilangan? Begitu pedih dan menyiksa.”(Nucke, 2015).

Bersumber pada kutipan dialog di atas digambarkan Khumairah yang sebelumnya merasa tenang kemudian bagaimana Khumairah dengan wajah cemas, gelisah, memerah menahan kecewa karena rasa panik mencari suaminya yang berpamitan tadi malam hanya meminta izin untuk melakukan itikaf di makam Rasulullah, dan hingga pagi belum juga kembali.

"Maaf, Mas! Kenapa kamu mempertanyakan soal itu? Apakah ada yang tidak berkenan dari sikapku hingga membuatmu merasa harus aku curigai?" (Nucke, 2015).
Gambaran yang diungkapkan pada dialog di atas digambarkan untuk menjaga benar ucapannya kepada Zidan dan Khumairah yang sebelumnya menjadi wanita kuat namun harus begitu lemah dan bagaimana Khumairah sebagai istri tidak memiliki kekuatan apa pun untuk menentang kata-kata dari suaminya, Khumairah dengan nada yang sangat berhati-hati menjaga nada bicara kepada Zidan agar tidak tersulut emosi.

"Hukum aku, Mas! Jika itu bisa meringankan beban kecewamu! Aku berharap maaf darimu! Demi Allah, penyelesalanku sungguh tak terhingga!'(Nucke, 2015).

Penggalan kalimat pada dialog di atas bagaimana Khumairah merasa tertekan dengan sikap suaminya, Khumairah sebagai seorang perempuan luar biasa yang memiliki kecerdasan intelektual dan sebagai seorang dokter rela berlutut dihadapan Zidan hanya sekedar untuk meminta maaf dan mempertaruhkan harkat dan martabatnya sebagai seorang istri.

"Sekali lagi aku minta maaf, Mas!
Tadinya aku fikir jauh lebih bijaksana
kalau kita mengalah dengan
mempersilahkan mereka turun lebih
dulu. Kita ini termasuk jamaah yang
paling muda. Jadi harus menghormati
yang lebih tua." (Nuche, 2015).

Kutipan kalimat di atas digambarkan Khumairah merasa menyesal dan merasa harus segera meminta maaf walaupun dalam hatinya dia tetap merasa bingung hanya karena dirinya ingin melakukan amal kabaikan namun Khumairah harus menekan semua kebingungannya agar dapat menjaga perasaan Zidan yang sifatnya sulit ditebak. 
"Puji syukur ke hadirat-Mu, yaa Rabb.

Telah Engkau berikan aku kesempatan untuk merasakan cinta suamiku di Tanah Haraam. Sesuatu yang nyaris hilang dalam kebersamaan kami selama ini."(Nucke, 2015).

Pada kutipan di atas digambarkan Khumairah tidak ingin suaminya tahu apa yang dia rasakan termasuk rasa takutnya kehilangan cinta Zidan yang mulai dia rasakan beberapa waktu belakangan ini.

"Walau diam-diam aku bisa menangkap perasaan kecewa yang coba mereka tahan saat aku menyatakan siap menerima pinangan Zidan. Aku ingat, kala itu sepasang mata ibuku yang penuh kesejukan seperti menyiratkan sebuah isyarat. Sayangnya, rasa gembira membuatku luput memahami makna di balik sorot berduka mata ibuku. Cinta telah menutup nalar dan logika yang seharusnya menjadi benteng pertahananku." (Nuche, 2015).

Kutipan dialog di atas digambarkan ada beban karena keluarganya menolak Zidan sebagai suaminya, namun Khumairah tetap tegar dan menerima segala kekurangan suaminya dan meyakinkan dirinya untuk berjuang bahagia bersama suami yang sangat dicintai.

"Maaf, saya gagal membantu meyakinkan mereka. Tapi saya paham kenapa mereka tidak bisa menjualnya kepada Anda. Soalnya gelang itu sudah lebih dulu dipesan. Dan, katanya, si pemesan juga jamaah dari Indonesia.” (Nucke, 2015).

Kalimat pada kutipan di atas digambarkan wajah Khumairah langsung berubah kecewa karena gelang yang dia inginkan sudah dipesan orang lain, dan dia coba meyakinkan kepada penjual agar dapat menjual gelang tersebut kepadanya, namun, Khumairah dengan cepat dapat menguasai emosinya hingga mampu menerima alasan penolakannya itu.

"Suamiku, doa apakah gerangan yang sedang kau panjatkan pada Tuhanmu? Mungkinkah kau sedang meminta pengampunan dosa atas kekejamanmu mengkhianati aku? Masihkah ada gunanya permohonanmu jika terhadapku kau gentar membuat pengakuan? Padahal aku menunggu kejujuranmu, suamiku. Sehingga aku bisa memutuskan apakah harus melanjutkan ikatan sakral pernikahan kita atau membuatnya terputus di persimpangan?" (Nucke, 2015).

$$
\text { Pada kutipan di atas }
$$
menggambarkan perasaan Khumairah yang tiba-tiba merasa kesal dengan ketidakberdayaannya sebagai istri, namun Khumairah tetap berusaha sabar dan menenangkan hatinya yang sebelumnya merasa tidak nyaman berada bersama Zidan.

“Kamu tidak bisa menutup mata dari
semua kekejaman yang dilakukan
siamimu. Memaafkan sebuah
pengkhianatan?" (Nucke, 2015).

Bersumber pada kutipan dialog merupakan kata-kata dari Gibran untuk menyadarkan Khumairah dari sikap pasrahnya kepada suami.

"Takdir mempertemukan orang-orang yang dikehendaki-Nya. Dalam keterasingan jiwa yang kosong atau kegundahan hati yang tersembunyi, pada akhirnya cinta yang palsu akan 
menemukan jalan untuk membuktikan dusta." (Nucke, 2015).

Selama berbulan-bulan terpuruk dalam kehancuran, Khumairah akhirnya mencoba bangkit sedikit demi sedikit. Meski pun Khumairah tahu bahwa mungkin hatinya tak akan bisa kembali lagi utuh seperti sedia kala, namun setidaknya kini Khumairah bisa sedikit demi sedikit menerima masa lalunya.

"Kehadiran Gibran menyeimbangkan isi pikiran Khumairah, kendati wanita itu menyangkal. Di mata Gibran Khumairah terlalu banyak berkorban. Mencintai seseorang tidak harus menzhalimi diri sendiri, tetapi Khumaira memilih berdamai. Ia ingin melihat Zidan bahagia menjadi seorang ayah." (Nucke, 2015).

Khumairah adalah wanita yang benarbenar memiliki hati teramat luas, ia bersedia menolong istri muda suaminya ketika melahirkan anak dari suaminya. Kelemahan Khumaira sekaligus menjadi kekuatannya dalam mencintai Zidan karena Allah. Namun pada akhirnya perpisahan tak lagi dapat dihindari.

"Padahal aku telah berjuang memberi kebanggaan sebagai perempuan mandiri! Aku rela berbagi beban finansial dengannya, tapi kenapa semua itu tidak cukup baginya hingga aku harus berhadapan dengan kenyataan pahit pernikahan' Suara hati Khumairah terdengar pilu. Padahal seharusnya dia merasa bangga dengan semua yang sudah diraih. Khumairah punya segudang prestasi. Terlihat dari berbagai macam piagam penghargaan di dinding ruang kerjanya. Belum lagi pulihan piala dan tropi berhasil dia sabet dari berbagai ajang lomba. Boleh dibilang
Khumairah perempuan yang sempurna. Cantik, Sholeha, dan berkarir gemilang. Para perempuan di rumah sakit itu bermimpi bisa seperti Khumairah” (Nucke, 2015).

Pada kutipan di atas sakit yang dirasa, kecewa dan penuh dengan kesedihan, tapi khumairah tetap dalam istiqomahnya, dia tak ingin tersesat dalam cinta yang penuh dengan dendam, dan inilah pengorbanan utuh penuh dengan keikhlasan, khumairah rela menyaksikan cintanya bahagia walaupun terluka.

"Viola?! Bagaimana Anda bisa menemukan saya?! Eh, maksud saya, lama tidak berjumpa. Bagaimana kabar Anda sepulang dari Tanah Suci?" (Nucke, 2015)

Kutipan kalimat di atas tergambar saat Khumairah yang sebelumnya fokus dalam bekerja tiba-tiba harus merasakan perasaan kaget, bingung, dan pahit karena luka yang telah digoreskan oleh Zidan. Khumairah berusaha menyembunyikan kepanikannya berhadapan dengan perempuan yang telah merebut suaminya, namun Khumairah terkesan basa basi untuk menyapa Viola.

"Insya Allah, bantuan itu akan kamu dapatkan! Saya berusaha semampu yang saya bisa saya lakukan. Tentunya semua berpulang pada ridha Allah! Perbanyaklah doa dan ibadah, baik wajib dan sunah! Juga jangan lupa untuk selalu beristighfar! Memohon ampunan Allah! Kamu mau berjanji untuk melaksanakan semua itu?" (Nucke, 2015).

Kalimat dialog yang ada di atas merupakan kalimat Khumairah yang 
ditujukan kepada Viola. Khumairah yang sebelumnya merasakan perasaan yang bercampur aduk antara emosi dan tugasnya sebagai dokter, namun dengan perasaan tenang Khumairah dapat mengendalikan emosinya dan dapat dengan lega berhadapan dengan wanita idaman lain suaminya.

"Aku berlutut di kakimu! Berharap
pengertian darimu! Maafkan
kecurigaan keluargaku! Percayalah,
Mas! Aku tidak akan terpengaruh!
Aku bersungguh-sungguh dengan
permintaan maaf ini!" (Nucke, 2015).

Pada kutipan di atas, Khumairah dengan segera memohon kepada Zidan, walaupun hatinya harus menahan rasa pahit menerima keterpaksaan sebuah kebenaran. Padahal sebelumnya Khumairah sangat bangga memperjuangkan kesetaraan gender, namun kini Khumairah sendiri yang harus merasakan bagaimana harus berpasrah diri menahan atas ketidakadilan yang dilakukan Zidan kepadanya.

"Apapun yang bisa menghapus
kesalahnku di matamu. Insya Allah
aku siap menerima hukuman!
Percayalah, tidak akan ada bantahan
dari mulutku." (Nucke, 2015).

Hal yang tergambar pada kutipan di atas yaitu sikap Khumairah yang berusaha untuk kuat dan tidak menangis di hadapan Zidan. Walaupun sebelumnya Khumairah sangat ingin marah atas perbuatan suaminya, namun semuanya harus Khumairah singkirkan hanya untuk meredam amarah Zidan, sehingga Khumairah rela menghambakan diri kepada Zidan.

"Insya Allah, aku akan menjawab semua pertanyaan itu! Tapi tidak sekarang karena ada yang lebih penting untuk kita urus. Yaitu Viola dan anakmu. Darah dagingmu. Dialah keajaiban yang diciptakan Allah dan harus kita sambut dengan sujud syukur!" (Nucke, 2015).

Gambaran yang terlihat adalah bagaimana perubahan sikap Khumairah kepada Zidan yang begitu dingin, Khumairah yang sebelumnya sangat santun kepada Zidan, kini sikapnya hanya tersenyum tanpa mau menanggapi rasa bersalah Zidan, kemudian dia pergi meninggalkan Zidan yang hanya terdiam.

\section{Perubahan Psikologi Tokoh Zidan}

Analisis bentuk perubahan psikologi tokoh Zidan dalam novel Cinta di Tanah Haram karya Nucke Rahma dalam dilihat pada kutipan berikut.

"Baiklah, aku akan memaafkan! Tapi
sebelumnya, aku ingin bertanya! Apa
maksudmu mencari-cari aku?
Tidakkah tindakan itu terlalu
berlebihan hingga kamu merasa
berhak melaporkan aku pada orang-
orang itu? Sadarkah kamu, Mai?
Kamu sudah mempermalukan aku
dengan menempatkan diriku seperti
seorang penjahat."(Nucke, 2015).

Kutipan kalimat di atas digambarkan perasaan Khumairah yang sebelumnya bingung, takut, dan cemas sampai panik karena kehilangan Zidan yang tidak pulang semalaman tiba-tiba merasa terpojok dengan pertanyaan dari Zidan yang bertubi-tubi.

"Bangunlah, Mai! Sebetulnya aku tidak berharap kamu akan mengiba seperti ini! Aku tidak ingin berbuat kejam terhadapmu." 
Volume 2, Nomor 1, Januari 2020 ISSN 2655-3031 (P), 2655-7851 (O)

"Mai, istriku! Atas alasan apa aku tidak memberimu maaf." (Nucke, 2015).

Pada kalimat kutipan di atas digambarkan bagaimana Zidan terkesan menikmati kelemahan sang istri, walau pada dasarnya dia menolak penghambaan diri perempuan di zaman modern, namun Zidan membutuhkan lebih dari sekedar kepatuhan seorang istri.

"Mai...pandang aku! Tataplah aku!" "Aku ini laki-laki keras dan penuh amarah! Tidak ada yang bisa aku janjikan untuk mengubah semua itu! Mungkin akan banyak kesedihan yang kamu rasakan dan itu bisa membuatmu kecewa! Sekarang biarkan aku bertanya! Kamu yakin masih mencintaiku!"' (Nucke, 2015).

Kalimat di atas diucapkan Zidan dengan keberanian, karena sebelumnya Zidan yang penuh perasaan amarah dan keangkuhan kepada Khumairah tiba-tiba harus pasrah dan menerima kenyataan jika harus berpisah dengan Khumairah.

"Baiklah. Kita akan mencoba sekali lagi untuk mempertahankan pernikahan ini! Dan aku akan memulainya dengan memaafkanmu! Kemarilah, biarkan aku memelukmu!" (Nucke, 2015).

Gambaran pada kutipan di atas, bagaimana perubahan sikap Zidan kepada Khumairah yang sebelumnya dipenuhi dengan amarah namun kini Zidan berubah menjadi lelaki yang memiliki sikap hangat kepada Khumairah hanya untuk menutupi rasa bersalahnya kepada istrinya.

\section{Perubahan Psikologi Tokoh Gibran}

Analisis bentuk perubahan psikologi tokoh Gibran dalam novel Cinta di Tanah Haram karya Nucke Rahma dalam dilihat pada kutipan berikut.

"Belum terlalu lama, tapi rasanya cukup buat saya menilai seperti apa kualitas pernikahan Anda! Yang jelas, kesalahan ada di pihak suamimu. Dia telah gagal menjaga amanah pernikahan. Bisa dibilang suamimu tipe laki-laki pengkhianat." (Nucke, 2015).

Pada kutipan di atas digambarkan bagaimana penilaian Gibran terhadap suami Khumairah, walaupun Gibran belum mengenal Zidan namun terlihat bahwa Gibran menaruh iba terhadap Khumairah yang telah disakiti.

\section{Perubahan Psikologi Tokoh Viola}

Analisis bentuk perubahan psikologi tokoh Viola dalam novel Cinta di Tanah Haram karya Nucke Rahma dalam dilihat pada kutipan berikut.

"Terlalu kamu, Zidan! Secara tidak sadar kamu sudah merendahkan aku! Padahal aku yang selalu memberimu kepuasan! Engkau mencarinya padaku, bukan pada istrimu yang mandul itu. Namun, kenapa engkau selalu menempatkan perempuan mandul itu dalam posisi jauh di atasku?" (Nucke, 2015).

Gambaran yang terdapat pada kalimat di atas terlihat bagaimana Viona marah kepada Zidan yang merasa diperlakukan tidak adil oleh Zidan. Padahal sebelumnya Viona selalu mengharapkan hanya dia yang ada dalam fikiran Zidan sepenuhnya. 
"Dokter tahu apa yang paling menyakitkan dari semua itu? Saya rasa suami saya menyesal telah mengkhianati istrinya! Itu sebabnya saya tidak pernah mau tahu tentang istri pertamanya! Mendengar namanya saja sudah membuat hati saya sakit! Luar biasa sakit." (Nucke, 2015).

Kutipan kalimat di atas terlihat sebelumnya sikap Viola yang biasa saja tibatiba berubah ketika harus berbicara tentang istri pertama Zidan yang tidak lain adalah Khumairah sendiri, namun Viola tidak mengetahui akan hal itu, Viola tiba-tiba menangis dan memeluk Khumairah untuk mendapatkan ketenangan.

\section{Pembahasan}

Perubahan psikologis tokoh Khumairah dalam novel Cinta ditanah Haram Karya Nucke Rahma yaitu menceritakan sosok Khumairah yang luar biasa, kuat, dan tangguh dalam menghadapi masalah. Khumairah yang awalnya bersikap ramah, tamah, sopan santun terhadap suaminya. Tetapi setelah Khumairah mengetahui bahwa suaminya memiliki istri kedua, hati Khumairah benar-benar sakit dan shock berat karena tidak percaya peristiwa itu akan terjadi dalam pernikahan mereka. Sifat Khumairah berubah, Khumairah lebih banyak diam karena takut kehilangan sosok suami yang sangat dicintainya, karena suaminyalah alasan Khumairah bertahan hidup.

Perubahan psikologi tokoh Zidan dalam novel Cinta ditanah Haram Karya Nucke Rahma yaitu menceritakan sosok Zidan sebagai suami yang sebelumnya sangat menyayangi istrinya, namun hanya karena Khumairah belum dapat memberikan keturunan, Zidan kemudian berubah dan bersikap semena-mena kepada istrinya, Zidan yang secara sadar selalu menyakiti dan menekan bathin Khumairah hanya untuk menutupi kesalahannya yaitu menikah lagi tanpa sepengetahuan Khumairah, namun akhirnya Zidan sadar, menyesal dan bertaubat dengan sikap angkuh dan egoisnya sehingga Zidan ingin kembali kepada Khumairah, namun semuanya terlambat karena Khumairah lebih memilih Gibran sebagai pendaping hidupnya.

Perubahan psikologi tokoh Zidan dalam novel Cinta ditanah Haram Karya Nucke Rahma yaitu perubahan sikap yang awalnya hanya simpati melihat Khumairah yang begitu tersakiti karena perilaku Zidan yang semena-mena menekan perasaan Khumairah, hingga akhirnya Gibran menaruh perasaan kepada Khumairah dan berusaha menjadi pendamping Khumairah selamanya.

Perubahan psikologi tokoh Viola dalam novel Cinta ditanah Haram Karya Nucke Rahma yaitu terlihat saat Viola begitu bangga dapat memenuhi keinginan Zidan untuk memperoleh seorang anak, dan bangga bahwa Viola lebih baik dari Khumairah, namun perasaan Viola tersakiti ketika Zidan yang terus menerus masih berharap dan menganggap Khumairah adalah segalanya dalam hidup Zidan, dan pada akhirnya Viola harus menyerah dan pasrah bahwa Zidan lebih mencintai istrinya, dan akhirnya Viola harus menerima kenyataan pahit diceraikan oleh Zidan.

\section{Simpulan}

Perubahan psikologi yang banyak terjadi dalam novel Cinta ditanah Haram Karya Nucke Rahma adalah perubahan sikap pada tokoh-tokoh utama 
yang harus merasakan bagaimana harus berpasrah diri menahan atas ketidakadilan. Sakit yang dirasa, kecewa dan penuh dengan kesedihan, namun tetap dalam istiqomah, Penggambaran bagaimana sakitnya di poligami dan ketidakjujuran dalam menjalin suatu hubungan. Cerita di dalam novel ini mengingatkan kita banyak hal. Tentang pengabdian pada suami yang sebaiknya logis tanpa menzholimi diri sendiri. Tentang bagaimana menghadapi masalah yang bertubi-tubi, lalu bangkit dari keterperukan itu. Dengan demikian poligami yang terjadi tentu akan memberikan dampak perubahan pada wanita.

\section{Daftar Pustaka}

Ahmad. 2007. Poligami Berkah Atau Musibah. Jakarta: Dar Al-Afaq AlArabiyyah.

Afrizal. 2015. Metodologi Penelitian Sastra. Yogyakarta. CAPS

Ardian, R, F.dkk. 2015.Poligami dalam hukum Islam dan Positif Indonesia .Volume Jurnal III .101. 1 April 2018 (Online) (https:// media. Neliti.com, diakses 1 April 2018).

Rahma, N. 2015.Cinta Ditanah Haram. Jakarta:PT. Onblos Creative.

Siswantoro. (2016). Metode penelitian sastra analisis struktur puisi. Yogyakarta:

Pustka Belajar.

Sujarwani. 2014. Psikologi Umum. Yogyakarta: CAPS.

Tsaniyatsnaini , Zukhruf Ghaida. 2019.

Kajian Sastra Novel "Lalita"

Karya Ayu Utami Melalui

Pendekatan Psikologi

Sastra. Disastra: $\quad$ Pendidikan

Bahasa dan Sastra Indonesia, Vol 1 No (2), 87-93. 